Pobrane z czasopisma Wschód Europy http://journals.umcs.pl/we Data: 26/04/2023 11:56:04

DOI:10.17951/we.2019.5.2.13-27 Wschód Europy • Восток Европы • East of Europe vol 5, 2 / 2019

Юлия Голубничая-Шленчак

ORCID: https://orcid.org/0000-0007-6597-4493

Историко-философский факультет, Киевский университет имени Бориса Гринченка, Украина

\title{
Литературные и литературно-юмористические журналы в лагерях интернированных воинов Армии УНР в Польше (1921-1923 гг.): тематическая наполненность и специфика издания
}

\section{Введение}

Лагерная пресса представляет собой колоссальный массив источников для исследователей лагерной повседневности и истории украинской периодики. Периодические издания в лагерях выполняли ряд функций, и прежде всего коммуникативную. Она заключалась в поддержании связи между интернированными в лагерях, украинской эмиграцией, как в Польше, так и за её пределами, а также с благотворительными организациями, в поддержке которых они были весьма заинтересованы. Журналы и газеты освещали проблемные моменты жизни в лагерях, информировали о трудностях пребывания в них (нехватка продуктов питания, медикаментов, одежды), публиковали объявления о розыске солдат и офицеров Армии УНР и др. Следующей не менее важной задачей была помощь «воину-собрату» в разрешении его психологических проблем, которые возникали в следствие неудач национально-освободительной борьбы и отсутствия стабильных перспектив в будущем. Воины основывали журналы, в том числе и с целью предоставить возможность интернированным на страницах изданий поделиться своей болью и найти поддержку среди единомышленников, помимо этого, объединить свои усилия вокруг общего дела, что также позволяло преодолеть угнетенное состояние, в котором они находились. Высмеивая отдельные негативные стороны своего пребывания в лагерях, авторы призывали воинов не сдаваться, а использовать это время с пользой для себя.

Важный вклад в исследование проблемы функционирования лагерной прессы и связанных с этим проблем было осуществлено Н. Сидоренко, которая в своей монографии «Духовно-национальное самоутверждение» проанализиро- 
вала основную тематическую направленность лагерных журналов и газет, а также периодичность их выхода ${ }^{1}$. Особого внимания для исследователей издательской деятельности украинской эмиграции заслуживает монография О. Вишки «Пресса украинской эмиграции в Польше 1920-1939», в которой автор приводит перечень периодических изданий, дает им содержательную и количественную характеристику ${ }^{2}$. Весомым вкладом в научную разработку данной проблемы стали также публикации современных украинских историков И. Срибняка, М. Павленко, А. Фуртеса. Среди польских исследователей следует особо отметить работы 3. Карпуса и А. Колянчука.

\section{Литературные журналы}

В лагере Калиш № 10 издавался литературный журнал 3-го конного полка 3-й Железной стрелковой дивизии - «За Украину». Этим занималась издательская секция общества «Просвита» упомянутого полка. Первый номер журнала вышел 28 мая 1921 г. Он задумывался как еженедельное издание, но как предупреждали сами издатели в № 3 - в связи с нехваткой средств журнал будет выходить нерегулярно 3 . Цена составляла 25 марок польских (далее - м. п.) В № 4-5 на обложке был помещён отрывок из песни «А ми ту червону калину підіймемо».

Журнал создавался с целью воспитания чувства национального достоинства, родного языка, истории и культуры, а также ознакомления читателей «как с лагерной, так и с недавно минувшей боевой жизнью» воинов ${ }^{4}$. Журнал содержал различные рассказы, повести, стихи, песни, воспоминания о боях и походах.

Первые числа тиражировались на шапирографе, правки вносились впоследствии от руки, одновременно сдвоенные номера 4/5 от 9 сентября 1921 г. и 6/7 от 10 ноября 1921 г. были изготовлены в типографском исполнении. За компликацию материалов № 3 отвечал хорунжий Хомичевский, информация о составителях других номеров отсутствует. Журнал начинался с освещения редакцией последних событий. В журнале печатались стихи В. Самойленка «Хозяин и вол» (№ 1), Г. Бучацкого «Проходит день» (№ 3), В. Яновского «Большевикам» (№ 4/5), П. Загоруйка «Осенние пения» (№ 6/7), стихи неизвестных авторов «Неверным сыновьям», «Рабам» (№ 4/5). Была отдельная рубрика «Казачье творчество». В ней были представлены стихотворение казака Ф. Ткача «Мысль казака», воспоминание «С восстания в 1918 г.» казака Т. Т-ч5 .

1 Н. М. Сидоренко, Національно-духовне самоствердження у 3 ч. Преса інтернованих украйнців та иивільної еміграції (Чехія, Польща, Румунія, Єгипет, 1919-1924), Київ 2000, т. 2, 262 с.

2 О. Вішка, Преса української емігращії в Польщі (1920-1939 рр.), Львів 2002, 479 с.

3 За Україну, Каліш: Видавнича секція т-ва «Просвіта» 3-го кінного полку, 1921, №3, 1 липня, c. 1.

4 За Україну, Каліш: Видавнича секція т-ва «Просвіта» 3-го кінного полку, 1921, № 1, 28 травня, c. 1.

5 За Україну, Каліш, Видавнича секція т-ва «Просвіта» 3-го кінного полку, 1921, № 6/7, 10 листопада, с. 22-24. 
На страницах журнала были опубликованы статьи «Еще несколько слов о предателях патриотов» С. Вильчакивського, «Не сила» П. Загоруйко, «Государственный язык» Л. А., «Царьград - Калиш» сотника Яновского (№ 4/5). Статьи сопровождались эпиграфами Наполеона Бонапарта, Т. Шевченко, И. Франко, Е. Чекаленко, Л. Украинки. В первом номере была напечатана пьеса «Суждено», посвященная проблемам крестьянства во времена национально-освободительного движения в Киевской области в 1918-1919 гг. ${ }^{6}$

Как и было запланировано редакцией - печатались воспоминания солдат о боевом прошлом (в № 1 - из боевой жизни 2-й сотни полка хорунжего К-к, в № 3 - «Из дорогих воспоминаний» и «Из жизни полка» неизвестных авторов). Также в журнале была рубрика «Всего понемногу», в которой печатались вести с Украины, новости повседневной жизни некоторых украинских и польских городов и колонку, посвященную спорту в лагере. В № 1 помещен фельетон Самуся «Всего понемногу», В котором новости были изложены в юмористически-иронической манере $\mathrm{e}^{7}$. В № 6/7 были напечатаны статьи, посвященные анализу прошедших событий. В частности, статья «Еврейской вопрос», в которой автор выразил свое возмущение совершенным еврейским погромом в Проскурове в феврале 1919 г., статья Радянина «Чего не сказал Скоропадский», посвященная анализу политики гетмана ${ }^{8}$. Иногда в конце номера подавались объявления. В частности, обращение одного из воинов о желании познакомиться с кем либо из женщин в лагере, но обязательно - «с лицом национально-сознательным и высоко идейным» ${ }^{9}$. Сдвоенный номер журнала (№ 6/7) стал последним, так как его издание было прекращено из-за недостатка средств.

Журнал «Литературно-военный вестник» («Літературно-військовий вісник») - издавался усилиями культурно-образовательного отдела 2-й Волынской стрелковой дивизии. Тиражировался в типографии 3-й Железной дивизии. В журнале был указан адрес редакции: Калиш, лагерь интернированных № 10. Первый номер журнала был посвящен годовщине начала Зимнего похода и, как и планировалось, вышел 6 декабря 1921 г. объемом в 58 страниц. Как отмечал О. Вишка, учитывая круг авторов «Литературно-военного вестника», его можно считать началом литературного журнала «Веселка», основанного в Калишском лагере в 1922 г.

На страницах журнала печатались стихи В. Конопацкого, Д. К-ОСК, Вовчка, А. Вина, В. Запонюка. Статьи на военную тематику принадлежат Г. Радченку, В. Кущу, В. Е., В. Сигариву. В журнале помещены два очерка - поэтический очерк, посвященный участникам Первого зимнего похода А. Падолиста «Вол-

6 Центральный государственный архив высших органов власти и управления Украины. (далее ЦГАВОВ Украины). Ф. 3525.Оп. 1.Д. 13. Л. 79.

7 Ibidem. Л. 80.

8 За Україну, Каліш: Видавнича секція т-ва «Просвіта» 3-го кінного полку, 1921, № 6/7, 10 листопада, с. 15-17.

9 ЦГАВОВ Украины. Ф. 3525. Оп. 1. Д. 13. Л. 121. 
шебная могила» и литературный очерк М. Сизого «Мои мечты». Имеются также короткие заметки о положении интернированных в лагере.

В лагере Пйотркув-Трибунальский с 1 марта 1921 г. начал выходить литературный двухнедельник «На волнах жизни» («На хвилях життя»). Издательством журнала занимался культурно-образовательный кружок штаба Армии УНР. Информация о месте издания журнала отсутствовала. Л. Бачинский, С. Краеугольный, Е. Мисило, А. Веретюк указывают как место издания лагерь Пйотркув-Трибунальский. Украинский историк И. Срибняк подтверждает это предположение, опираясь на архивные источники Центрального государственного исторического архива Украины в г. Львове ${ }^{10}$. О. Вишка в своей монографии отмечает, что В. Арнадиев, автор одной из статей, опубликованной в № 1 журнала, написал ее в лагере Пйотркув-Трибунальский. Только М. Мартынюк подает как место издания лагерь в Стшалково, но не дает никаких объяснений ${ }^{11}$.

Цель издания редакция сформулировала в обращении к читателям: «Своей целью журнал ставит правдиво освещать, насколько это будет возможно, с государственной, общественной и военной стороны, как общую украинскую, так и нашу казацкую лагерную жизнь, выявлять в ней недостатки и словом правды их исправлять» ${ }^{12}$. Издатели планировали размещать на страницах журнала статьи на различные темы, стихи, рассказы, отрывки из дневников, воспоминания о боевых походах воинов, рисунки и тому подобное.

Всего вышло два номера журнала. Авторами материалов, помещенных на страницах данного издания, были В. Арнадиев, Е. Маланюк, И. Мельник, М. Беспалко, Н. Гримало, В. Кущ. В них размещены два портрета Т. Шевченко и М. Омельяновича-Павленка, нарисованных В. Хмеликом.

\section{«Радуга - это конец вчерашней бури и минута покоя перед новым ураганом»}

3 мая 1922 г. состоялось собрание Калишского литературно-артистического общества «Венок» и молодых литераторов лагеря, которые не входили в состав общества. На собрании присутствовали С. Довгаль, М. Селегий, М. Загривный, Ю. Дараган, А. Падолист, И. Зубенко, А. Коршнивский, Ф. Крушинский и др. Целью собрания было основание литературного издательского органа. На заседании было принято решение о создании журнала «Радуга» («Веселка»). Был определен тематический репертуар журнала, а также было избрано редакционную коллегию. В результате голосования в нее вошли Ф. Крушинский, М. Селегий, А. Падолист, И. Зубенко, А. Коршнивский. С № 5 к редколлегии присоединился

10 І. Срібняк, Обеззброєна, але нескорена: Інтернована Армія УНР у таборах Польщі й Румунії (1921-1924 рр.), Київ-Філядельфія, 1997, с. 65.

11 М. Мартинюк, Українські періодичні видання Західної України, країн Центральної та Західної Європи (1914-1939 рр.), Львов, 1998, с. 123.

12 E. Wiszka, Prasa emigracji ukraińskiej w Polsce 1920-1939, Toruń 2001, s. 173. 
Е. Маланюк, а в № 11/12 её членами были указаны Ю. Дараган и А. Падолист. До марта 1923 г. ответственным редактором оставался Ф. Крушинский, впоследствии эту должность занял А. Коршнивский. 9 июня этого года общество «Венок» и журнал объединились под одним названием «Радуга». Сначала журнал издавал культурно-образовательный отдел 3-й Железной стрелковой дивизии, впоследствии эта функция перешла к издательству «Черномор» (№ 7/8 1923 г.) ${ }^{13}$.

Материалы и пожертвования на литературный фонд «Радуга» принимались по адресу: Калиш, ул. Липова 64, кв. 8 на имя Ф. Крушинского; в № 7/8 уже указывался другой адрес - ул. Чясна 17/3. Журнал также имел свое представительство в США и Канаде (находилось по адресу - Winchester ave Chikago, 2142, USA, Mr. Frank Timre).

Начальная цена номера составляла 150 м. п.; однако уже № 4/5/6 предлагалось приобрести по - 5000 м. п. На журнал можно было оформить подписку: отдельный номер с пересылкой (Польша, Украина, Германия, Австрия, Болгария) реализовался по цене 350 м. п., в другие страны - 700 м. п., в США и Канаду - 900 м. п.; при заказе оптом предоставлялась скидка 20\%. Цена варьировалась в зависимости от объема номера, материальных затрат на его издание и курса валют. Редакция обращалась к читателям с просьбой о финансовой поддержке: «...журнал «Веселка» не имеет никакой финансовой поддержки издательств, лиц или организаций, а является органом группы молодых литераторов и издается исключительно в надежде на помощь от мирных украинских граждан» (была размещена на оборотной стороне обложки № $5 »)^{14}$. В конце номера подавалась информация о пожертвованиях на прессовый фонд издательства за определенный период. Первый и второй номер 1922 г. разошлось тиражом в 200 экземпляров, третий и четвертый - 400, пятый - 500, сдвоенный номер 6/7/8 - 1000 экземпляров.

Сначала «Радуга» была ежемесячным литературным изданием, однако уже вскоре - для расширения круга читателей - переформатировалось в ежемесячный журнал литературы, искусства и общественной мысли: «Vesselka» («Larc en cel») Revue Ukrainienne de la littérature et de l’art »(№ 7/8 1923 г.). Причина выбора такого названия раскрыта в № 1 в обращении к читателям: «Радуга - это конец вчерашней бури и минута покоя перед новым ураганом». В первом номере журнала, вышедшем в мае 1922 г., редколлегия обратилась к украинской общественности с объяснением цели основания «Радуги»: «В надежде на его поддержку основываем свою «Радугу», желая объединить вокруг неё разнообразные наши литературные течения. Призываем к сотрудничеству, к реальной и материальной помощи» ${ }^{15}$.

13 Веселка, Каліш 1922, № 5, с. 1.

14 Ibidem.

15 Центральный государственный архив зарубежной украиники. Ф. 15. Оп. 1. Д. 65. Л. 18. 
В честь пятой годовщины провозглашения независимости Украины в № 1 1923 г. было опубликовано обращение к представителям искусства: «Вам, поэты, художники и музыканты, резчики и актеры украинские, история предписывает создать сейчас украинскую Легенду, спеть ПОЭМУ НАЦИИ (так в тексте - aвm.). Словом, краской, линией, жестом, звуком невероятно мощных маршей и гимнов вы должны организовать, зажечь народные массы и вдохновить их на последний беспощадный бой».

Основным материалом журнала стали стихи, пьесы, рассказы, новеллы, очерки, публиковались статьи и рецензии на произведения. «Радужная» хроника подавала информацию о жизни журнала и людей, причастных к его существованию, а рубрика «Почтовый ящик» давала ответы на письма читателей. Впоследствии добавились разделы «Общественное мнение», «Художественная трибуна», «Хроника», «Театр». Данные разделы были представлены статьями А. Карманюка («О политической эмиграции», «Драматическое общество Объединение»), Ю. Сирого («Леся Украинка» статья к 10-летию со дня смерти поэтессы), Д. Донцова ( «С неопределенного пути»), Е. Чеховича.

Проза на страницах журнала была представлена различными рассказами, новеллами, очерками, эссе, фельетонами. Это произведения Ларисы Эльде, М. Диканьки, М. Гривы и др. Также печатались пьесы или отрывки из них В. Пидмогильного («Смерть»), Ю. Косача («Под Дюнкерком»), О. Карманюка («Максим Свеней»), Ф. Крушинского («Мотря Кочубеевна»). В журнале «Веселка» свои стихи печатали А. Павлюк («Умирание»), Л. Миронюк («Небо звезды золотом сбили»), Е. Маланюк («Осенняя молитва»), М. Осыка («Накануне»), Дажбожич («Только намек»), Д. Загул («Реквием», стихи из цикла «Трубач»), М. Селегий («К музе»), А. Падолист (стихи из цикла «Взволнованное сердце»), Ю. Дараган («Черное», «Willa Otilka», «Стихотворения весенние»). За графическую составляющую и оформление журнала отвечали П. Омельченко, В. Дяденюк, А. Жуков, Зубко-Макиевский, В. Цимбал, М. Щербак.

Авторы часто брали себе псевдонимы. Н. Сидоренко в своей работе подает расшифровки некоторых из них: Аполлон Падолист - Александр Варавин, Алексей Карманюк - Анатолий Коршнивский, М. Осина - Михаил Островерх, Ивась Блакитный - И. Яблонский, Даниил Левский - Данилевский, Максим Грива носил фамилию Загривный, Николай Падоляк - Чарский, а Василий Лимниченко Мельник. Лариса Эльде вероятно Лидия Дучиминская, Галина Орливна - Маевская (Полищук), Борис Б. - Базилевич. Прекращение издания журнала «Радуга» в 1923 г. (последний № 11/12 вышел в декабре), было связанно с выездом почти всех его сотрудников на учёбу в Чехословакию или в разные города Польши ${ }^{16}$.

Литературно-военный журнал «Наша заря» («Наша зоря») изначально выходил в лагере Ланцут (барак № 10), затем в Стшалково (барак № 47, а затем

16 О. Колянчук, Украйнська військова еміграція в Польщзі 1920-1923 рр., Львів 2000, с. 111. 
Pobrane z czasopisma Wschód Europy http://journals.umcs.pl/we

Data: 26/04/2023 11:56:04

Литературные и литературно-юмористические журналы в лагерях интернированных...

49 б), а после этого в Калише (барак № 10) ${ }^{17}$. Журнал позиционировал себя как «орган независимой мысли» под лозунгом «Украинцы всех направлений объединяйтесь». Его изданием занималась культурно-образовательная комиссия лагеря. Главным редактором был Г. Симанцев, ответственным - А. Лебединский. Журнал печатался в типографии «Наша заря». Цена за экземпляр колебалась от 15 м. п. до 25 м. п.; в лагере, где на тот момент журнал издавался, его распространяли бесплатно. Первый номер журнала был изготовлен от руки и размножен на шапирографе. Следующие номера печатались, но продолжали тиражироваться таким же образом. Номера, изданные в Стшалково и Калише, были печатными. Сначала экземпляры были небольшие по объему - до 16 страниц, а затем увеличились до 40 страниц (№ 29-30).

Содержание каждого номера «Нашей зари» было наполнено стихами, рассказами, очерками, различными статьями, воспоминаниями, заметками. В Калишском журнале «Новое слово» (№ 1, апрель 1921 г.) содержалась короткая заметка о первых пяти номерах журнала «Наша заря». Редколлегия сетовала на то, что в журнале было опубликовано значительное количество переводов стихотворений, вместо творчества самых интернированных ${ }^{18}$. Например, в № 4 стихотворения «Утро» Детлефа фон Лилиенкрона в переводе А. Луцкого, «Расстрел» А. Оржиховского в переводе С. Пилькевич ${ }^{19}$.

В журнале были представлены рубрики «Вместо фельетона», «Письма в редакцию», «С украинской жизни на чужбине», «Из жизни лагеря». На страницах «Нашей зори» публиковались материалы А. Лебединского, С. Левченка, А. Сэммо, А. Пилькевича, Н. Шаповала, В. Ника, И. Блакитного, Е. Маланюка, В. Евтимовича, Г. Тупкала, Д. Геродота, А. Шмеля и др.

\section{Литературно-юмористические журналы. Журнал «Око» заглянет в самую душу}

Литературно-юмористический журнал 2-й Волынской стрелковой дивизии «Око» издавался регулярно, появляясь преимущественно в воскресенье. Первое число было напечатано 30 января 1921 г. Всего за период с конца января до конца июня 1921 г. вышло 22 номера. Однако весь тираж последнего был полностью конфискован без указания причины. Объем журнала составлял 15-20 страниц, а тираж - 20-30 экземпляров. Формат журнала был 24х33 см. В начале издания цена составляла 25 м. п., потом повысилась до 40 м. п. за экземпляр (№ 16 от 15 мая 1921 г.). Редактировала и издавала журнал инициативная группа, а начиная от № 16 - коллегия (которая находилась по адресу: Калиш, лагерь № 10).

17 О. Вішка, Преса української еміграції в Польщі (1920-1939 рр.), Львів 2002, с. 241.

18 ЦГАВОВ Украины. Ф. 2373. Оп. 3. Д. 8. Л. 111.

19 Ibidem. Л. 45. 
Журнал печатали на машинке и копировали на шапирографе, поэтому порой текст был довольно нечетким. Обложка рисовалась от руки, на ней указывалось содержание числа, адрес издания, иногда цена. Под названием журнала «Око» было указано «заглянет в душу глубоко, глубоко» ${ }^{20}$.

В первом номере редакция объясняла цель создания журнала: «Это „Око” прежде всего хочет завязать связи со всеми группами украинских граждан, разбросанных по Польше. Далее „Око” должно упорно бороться с той анархией, малодушием, и иногда провокационными слухами, которые так негативно отражаются на наших нравственных чувствах. В одиночестве „Око” должно оглянуться назад, на путь, что был пройден, и всесторонне проштудировать и проанализировать его» (№ 1 от 30 января 1921 г.). Журнал хоть и имел литературно-юмористическое направление, на своих страницах помещал достаточно разнообразную информацию.

Номер обычно начинался с анализа ситуации в мире на момент выхода журнала. Например, № 8 от 20 марта 1921 г. начинается с оценки П. Гладкого восстания в Кронштадте, «которое блеснуло как звезда надежды для всех, кому близка воля народа...». Автор осуждает политику стран Западной Европы, ведь «...он [Запад] - одной рукой подписывает торговый договор с представителями хищнического правительства России, цинично в тот же миг, как старцам, шлет кусочек хлеба борцам за свободу от узурпаторов Ленина и Троцкого». Завершалось обращение редакции подведением итогов относительно будущей судьбы России. «Устои самодержавного узурпаторского трона подорваны и на все время трон тот осужден на вечное шатание» ${ }^{21}$.

Авторами стихов в журнале были В. Конопацкий - иногда указывались только инициалы В. К. («Прошлое», «Последние минуты Гетмана Полуботка»), А. Мусияк - А. М. («Рыцарям зимнего похода», «Встреча атамана») Гром-Устименко («Я видел во сне»), Мизерный («С. А. Загродского»), В. Смутной («Синим орлам»), А. Заворицкий («Злободневно»), Д. Бурко («Памятник памяти И. Франко»), Я. Лужик («Днепр»), Писарь Крючок («Злободневец»), А. Вертинский, Ф. Раевский.

Иногда в журнале публиковались пьесы авторства преимущественно В. Смутного. В частности, «Красный Арлекин - современная арлекинада на I акт», пьеса, события которой разворачиваются во время революции на территории Украины в каком-то, не указанном автором, большом городе в 1919 г. 22 Главными героями выступают Пьеро, Коломбина, Пьеретта, Арлекин и два солдата-коммуниста. Следующие его пьесы «На распутье» и «Победители» также посвящены проблемам национально-освободительной борьбы украинского народа. Кроме этого был напечатан сценарий лагерной постановки Михаила

20 ЦГАВОВ Украины. Ф. 3525. Оп. 1. Д. 14. Л. 61.

21 Ibidem. Л. 11.

22 ЦГАВОВ Украины. Ф. 3525. Оп. 1. Д. 14. Л. 23-24. 
К. «Ревизор» ${ }^{23}$. Представлены рассказы Журбы «Отец», В. Смутного «Заснул», Д. Бурка «За родной край».

Постоянными рубриками журнала были «Из лагерной жизни», «Наша хроника», «История 2-й Волынской стрелковой дивизии», «Наша энциклопедия», от № 11 начинают появляться статьи, посвященные вопросам медицины и здравоохранения. В рубриках «Из лагерной жизни» и «Наша хроника» освещалась информация, касающаяся различных аспектов жизни в лагере и вне его (подрубрики - язык, театр, спорт и развлечения, праздники и годовщины, политика, лагерь и город, культурно-образовательная деятельность и др.). Автором большинства статей для данных рубрик являлся Михаил К., реже корреспондентом был В. Смутной. Также в рамках этих рубрик печатались фрагменты из дневников и очерки военнослужащих о пребывании в лагере. В частности, из записи дневника от 21 ноября 1921 г. вышеупомянутого Михаила К., можно узнать об организации старшинского вечера отдыха в лагере: «Готовимся к старшинской вечеринке. Признали, очевидно, Японию (размышлял автор статьи - aвт. ), а потому делаем японские фонарики. Цены на цветную бумагу, краски и строительные материалы поднялись на $100 \%{ }^{24}$. Счета оплачиваются гербовыми марками». Подавались обзоры лагерных театральных представлений, в частности, комедии И. Карпенко-Карого «Мартын Боруля», которая состоялась в понедельник 27 февраля 1921 г. ${ }^{25} \mathrm{~B}$ журнале также писалось об инспекции С. Петлюры (№ 11) и визите Ю. Пилсудского (№ 17) в лагерь. В конце № 4 от 20 февраля 1921 г. редакция обращается к читателям и сотрудникам с просьбой приобщиться к написанию истории дивизии. Начиная с № 5, регулярно велась рубрика «История 2-й Волынской стрелковой дивизии», автором которой был В. Конопацкий.

Достаточно нетипичной была рубрика, посвященная охране здоровья, которую вел Л. Бачинский. Она содержала лекцию о вреде табака (№ 11), развернутую статью, в которой говорилось об опасности для жизни паразита солитера (№ 16) и лекцию о венерических болезнях (№ 20).

Как и положено юмористическим изданиям, журнал содержал соответствующую рубрику «Наша энциклопедия». Она велась в виде толкового словаря, где на каждую букву был тематический подбор слов и определений их с точки зрения солдат. Например: Антанта - союз государств, интересующихся Полтавскими хлебом, Киевским сахаром, Екатеринославскими приисками; буфет - институция, которая уже выкачала все марки в карманах старшин ${ }^{26}$; деньги - неизвестная нашему брату вещь ${ }^{27}$. Временами печатались статьи на болезненные для интернированных темы. Одной из таких была статья «Украинский язык»,

23 „Око”, Колегія 2-ої Волинської стрілецької дивізії, Каліш 1921, № 17, с. 16-17.

24 ЦГАВОВ Украины. Ф. 3525. Оп. 1. Д. 14. Л. 19.

25 Ibidem. Л. 101.

26 Ibidem. Л. 71.

27 Ibidem. Л. 9. 
автор которой призывал очистить ряды интернированных от тех, кто не владеет украинским языком ${ }^{28}$.

В журнале также размещались различные обращения, как самой редакции, так и читателей. В № 6 (от 6 марта 1921 г.) находим заметку о нехватке продовольствия в лагере в Пйотркове-Трибунальском и просьбу о помощи «сослуживцам с седьмой бригады». В № 19 (от 5 июня 1921 г.) было напечатано обращение с призывом вносить пожертвования в фонд сооружения памятника И. Франко.

Часто в конце отдельных номеров «Ока» подавались различные объявления. В частности, объявление о том, что при редакции открыта студия фотографии. Подано цены за фотографии размером с открытку (3 фотографии - 10 м. п., 6 120 м. п., 12 - 250 м. п.) и расписание работы студии (воскресенье - 10 - 12 часов и с 14 до 16 часов дня, в четверг с 12 до 15 часов дня) ${ }^{29}$.

По случаю важных событий издавались тематические номера - № 6 от 10 марта 1921 г. был посвящен 60-й годовщине со дня смерти Т. Шевченко. В этом номере содержались стихи П. Гладкого («Под бедной крышей, у бедных родителей», «Красота Украины, поэт наша слава»), А. Заворицкого («Сегодня день большого праздника»), В. Смутного («Развернулась веселая») статья Т. П. «Национальные мотивы творчества Т. Шевченко». Сдвоенный № 9 - 10 от 30 марта 1921 г. был посвящен событиям I-го Зимнего похода. В номере было представлено несколько портретов участников Зимнего похода: генерал-поручика М. В. Омельяновича-Павленко, генерал-хорунжего А. А. Загродского, генерала А. С. Галкина, полковника А. И. Волосевича. Также есть карта Зимнего похода. Тематический № 21 посвящен памяти погибшим в войне 1917-1921 гг. Пасхальный выпуск (№ 14 от 1 мая 1921 г.) наполнен праздничными поздравлениями, рассказами и стихами П. Гладкого, В. Смутного, В. Конопацкого, А. Мусияка, Гайдамаки и др.

Журнал содержал рубрики «Из нашей прессы», «Из лагерной жизни», «Из жизни лагерного театра», «Теория журналистики», «Из наших мыслей», рубрику, посвященную проблеме образования в лагерях. Рубрика «Из лагерной жизни» подавала информацию о культурно-образовательной составляющей повседневности в лагерях. В частности, в № 5 описывается приезд Главного Атамана С. Петлюры в лагерь. По этому случаю спортивным отделом была организована олимпиада, представлены образцы творчества кружка «Возрождение» и выступления воспитанников танцевальной группы Авраменко, в завершение вечера лагерный театр подготовил постановку «Запорожец за Дунаем» ${ }^{30}$. Следующим достойным внимания событием был «День Белого цветка» - день помощи больным старшинам и казакам, которые находились в госпиталях. Рубрика «Из жизни лагерного театра» содержала развернутую статью, посвященную постановке драмы И. Тогобочного «Борцы за мечты», премьера которой состоялась 24 августа 1921 г.

\footnotetext{
28 Ibidem. Л. 25.

29 Ibidem. Л. 102 A.

30 Ibidem. Л. 75.
} 
Pobrane z czasopisma Wschód Europy http://journals.umcs.pl/we

Data: 26/04/2023 11:56:04

Литературные и литературно-юмористические журналы в лагерях интернированных...

На страницах журнала был опубликован целый ряд стихотворных форм (В. Конопацкий, Вовчок и др.), печатались рассказы («Американ» Вовчок), статьи («Национальные парки на Украине» Л. Бачинского), объявления. В № 8 отмечалось, что за неимением средств журнал будет выходить с опозданием, но, очевидно, этот номер стал последним ${ }^{31}$.

\section{«Сыч должен сычать на всех и каждого»}

«Сыч» - сатирико-юмористический и литературный журнал 7-й бригады 3-й Железной стрелковой дивизии. На обложке указан адрес - Калиш, лагерь № 10. Издательством, редактированием и печатью занималась коллегия. Цена экземпляра составляла 30 м. п. Журнал изготовлялся полностью от руки и тиражировался на шапирографе, поправки вносились уже после копирования. Для обложек использовалась разноцветная бумага, в частности, № 1 имеет оранжевую обложку, № 2 - фиолетовую. Формат издания 21х33см. Выбор названия объясняется тем, что «Сыч должен сычать на всех и каждого».

В № 1 опубликован рассказ о создании журнала. Были версии назвать журнал «Шершень», «Шмель», «Деркач», «Комар», «Оса», «Колючки», «Коса», но ни одно из названий не пришлось по душе его основателям. Один из интернированных начал высказывать нелестные мнения относительно основания журнала вообще, на что ему ответили, что он «всегда сычит, как тот сыч». Тогда и было решено, что было бы символично так и назвать издание - «Сыч» ${ }^{32} .28$ января 1921 г. вышел «первый номер «Сыча» в ночное время суток, как и положено настоящему сычу» ${ }^{33}$. Как отмечает О. Вишка, некоторые авторы (С. Краеугольный, Е. Мисило) подают неверное название журнала - «Сич» ${ }^{34}$.

Журнал содержал рубрики «Театральная хроника» и «Говорят». В первой дается обзор театральной жизни в лагере. Также тут представлена развернутая рецензия на постановки актерами-аматорами 3-й Железной стрелковой дивизии спектаклей «Сватовство на Гончаровке» Квитки-Основьяненко (8 января 1921 г.) и «Наталки Полтавки» И. Котляревского (22 января 1921 г.) $)^{35}$. В рубрике «Говорят» подавались различные заметки юмористического характера.

Авторы подписывались псевдонимами - «Пан», «Слобожанин», «Не галичанин», «Хомняк», «Зритель», «Грешный», «Не сотник, а хорунжий». Почти все карикатуры и рисунки принадлежат авторству Каран-Даша, кроме одного рисунка Богдановича. Литературная часть журнала содержит стихи авторов под псевдонимом "Пан” и “Выч", юмористические рассказы, в частности, «История малых королей» (автор “Пан”), «В школе подстаршин» (автора под псевдонимом “Не галичанин”),

31 Ibidem. Л. 103.

32 “Сич”, Каліш 1921, № 1, с. 3.

33 Ibidem.

34 О. Вішка, Преса української еміграції в Польщі (1920-1939 рр.), Львів 2002, с. 283.

35 “Сич”, Каліш 1921, № 1, с. 16. 
«Из дневника» (автора "Не сотника, а хорунжего"), юмористически-сатирические статьи «В неволе у большевиков» и «Впечатления очевидца от пребывания в городах Волыни» ${ }^{36}$. Редакция обращалась с просьбой присылать материалы для издания по указанному адресу, однако второй номер «Сыча» стал последним.

\section{Издательство журнала «Кандалы»}

В лагере Вадовице выходил литературно-юмористический журнал «Кандалы» («Кайдани») издательства «Просвита» Конного им. И. Мазепы полка 2-й Волынской стрелковой дивизии. В 1921 г. вышел один номер этого журнала объемом 32 страницы и форматом $15 \times 21$ см., причем не были указаны его тираж и цена. Журнал был напечатан на машинке и размножен с помощью шапирографа, обложка нарисована от руки.

Редакция журнала обращалась к читателям с призывом присылать свои произведения, поэтому адрес указан четко, но в стихотворной юмористической форме, как свойственно таким изданиям: «Барак 13 ищите, Туда бумаги приносите, Там редакция ютится, Ибо хвори не боится, Николай, но не второй».

Редактор «Николай», как можно понять из стихотворения, так объясняет цель издания журнала: «Наша цель этим журналом правильно повлиять на жизнь казака, а также дать офицерам маленькое развлечение и посодействовать пробуждению в них творческого духа». Информация, представленная на страницах этого журнала, была весьма разнообразной. Печатались стихи, смешные рассказы, исторические воспоминания, например, о гетмане Иване Мазепе, различные рисунки и др.

\section{Выводы}

Литературные и литературно-юмористические журналы представляют особый вид лагерной периодики, так как в них подавалась информация о разных аспектах повседневной жизни интернированных. В частности, на страницах периодики авторы писали о проблемах быта (оснащение бараков, обеспечение продуктами питания, гигиена и здоровье и т.д.) и о проведении культурно-образовательной работы среди воинов. С помощью этих материалов можно реконструировать период интернирования и попытаться воссоздать тот повседневный быт, с которым каждый день сталкивались воины Армии УНР в лагерях Польши 1921-1923 гг.

Их уникальность заключается и в том, что лагерная периодика дает возможность проследить изменение морально-психологического состояния военнослужащих в течение всего периода интернирования. Ведь в стихах, рассказах, новеллах воины воплощали свои переживания, надежды. Кроме этого, данные произведения являются прекрасными образцами военного литературного творчества. Также особого внимания заслуживают иллюстрации. В частности, портреты генералов и офицеров, а также различные зарисовки лагерных художников.

36 “Сич”, Каліш 1921, № 2, с. 3-18. 
Pobrane z czasopisma Wschód Europy http://journals.umcs.pl/we

Data: 26/04/2023 11:56:04

Литературные и литературно-юмористические журналы в лагерях интернированных...

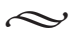

Аннотация: С подписанием в 1921 году Рижского мирного договора между Польшей и РСФСР у политического руководства УНР уже не было никаких оснований надеяться на активную поддержку борьбы с большевизмом со стороны Варшавы. Поражение Второго зимнего похода под командованием генерала Ю. Тютюнника побудило Государственный Центр УНР в экзиле временно отказаться от планов восстановления украинской государственности вооруженным путем. Интернированные солдаты Армии УНР оказались в тяжелых условиях. Инструментом для преодоления деморализации в лагерях стала образовательно-культурная деятельность, одним из основных ключей которой была издательская. Лагерная пресса является отражением тех взглядов и идей, которые были распространены среди интернированных.

Издательство газет и журналов стало мощным фактором национально-патриотического единения и мобилизации интернированного воинства под лозунгами возрождения УНР. Кроме этого большое внимание уделялось повышению уровня культуры воинов.

В статье анализируется процесс издательства литературных и литературно-юмористических журналов и газет, издаваемых интернированными Армии УНР в лагерях Польши в 19211923 гг. На основе массива архивных источников и специальной литературы приводится информация о тематике публикаций и их авторах, периодичности и места издания, цене, составе редакции. Сделаны выводы об авторитетности издания и отношении к ним самих интернированных. Редколлегии лагерных газет и журналов сделали весомый вклад в дело сплочения интернированного украинского воинства и его национально-патриотического воспитания. Издательская деятельность интернированных украинских воинов в лагерях Польши является важным источником для исследования многих аспектов жизни украинской эмиграции, а именно, политического, экономического, образовательного, культурного и др.

Ключевые слова: лагерь, Армия УНР, интернированные, издательство, пресса, Польша.

\section{Literackie i literacko-humorystyczne czasopisma w obozach internowanych żołnierzy armii Ukraińskiej Republiki Ludowej w Polsce (1921-1923)}

Streszczenie: Tematem artykułu jest jakościowa i ilościowa charakterystyka czasopism, wydawanych przez internowanych Ukraińców w polskich obozach w latach 1921-1923. Przebywający w trudnych warunkach oficerowie i żołnierze Armii URL potrzebowali zarówno wsparcia psychicznego, jak i informacji o sytuacji panującej w pozostałych obozach. Zadanie to z powodzeniem wypełniały liczne wydawnictwa ciągłe. Jednym z rodzajów były czasopisma literackie i humorystyczne. Tego typu wydania zawierały utwory literackie, wiersze, opowiadania, sztuki teatralne, wspomnienia żołnierzy, omówienia i recenzje, humoreski, anegdoty i inne. Artykuł jest oparty na źródłach archiwalnych, prasie obozowej oraz pracach historyków polskich i ukraińskich.

Słowa kluczowe: czasopismo, gazeta, internowany, obóz, Polska, armia Ukraińska Republiki Ludowej, Kalisz, Wadowice. 


\title{
Literary and literary-humorous magazines in camps for interned soldiers of the Army of the UPR in Poland (1921-1923): the specifics and features of the publication
}

\begin{abstract}
With the signing in 1921 of the Riga Peace Treaty between Poland and the RSFSR, the political leadership of the UPR had no reason to hope for Warsaw's active support in the fight against Bolshevism. Being trapped in difficult conditions of internment in Polish camps, Ukrainian soldiers needed psychological support and communication, and these tasks were fulfilled by the camp periodicals. Some of these magazines were literary and literary-humorous. The article based on an analysis of the works of Polish and Ukrainian researchers of the given period, as well as a corpus of archival sources provide a qualitative and quantitative description of the periodicals published in the camps in 1921-1923. The journals represent a special type of camp periodicals, since they contain information about various aspects of the daily life of the internees and information about the moral and psychological state of the warriors. In addition, these works are excellent examples of military literary work. The editorial boards of camp newspapers and magazines made a significant contribution to the cause of rallying the interned Ukrainian army and its national-patriotic education. The publishing activities of interned Ukrainian soldiers in the Polish camps is an important source for the study on many aspects of the life of Ukrainian emigration, namely, political, economic, educational, cultural, etc.
\end{abstract}

Keywords: newspapers, magazine, interned, camp, Poland, UPR Army, Wadowice, Kalisz.

\section{Литература}

„Oko", 22 travnya 1921, Kolehiya 2-oyi Volyns'koyi strilets'koyi dyviziyi, Kalish, № 17, 20 s.

"Oko", 5 chervnya 1921, Kolehiya 2-oyi Volyns'koyi strilets'koyi dyviziyi, Kalish, № 19, 20 s.

"Sych", 12 lyutoho 1921, 7-ma strilets'ka bryhada, Kalish, № 2, 26 s.

„Sych", 28 sichnya 1921, 7-ma strilets'ka bryhada, Kalish, № 1, 20 s.

„Veselka”, veresen' 1922, Kalish, № 5, 34 s.

"Za Ukrayinu”, 1 lypnya 1921, Vydavnycha sektsiya t-va «Prosvita» 3-ho kinnoho polku, Kalish, № 3, 15 s.

„Za Ukrayinu”, 10 lystopada 1921, Vydavnycha sektsiya t-va «Prosvita» 3-ho kinnoho polku, Kalish, № 6/7, 24 s.

„Za Ukrayinu”, 28 travnya 1921, Vydavnycha sektsiya t-va «Prosvita» 3-ho kinnoho polku, Kalish, № 1, $13 \mathrm{~s}$.

Kolyanchuk 0., Ukrayins'ka viys'kova emihratsiya v Pol'shchi 1920-1923 rr., L'viv 2000, 274 s.

Martynyuk M., Ukrayins'ki periodychni vydannya Zakhidnoyi Ukrayiny, krayin Tsentral'noyi ta Zakhidnoyi Yevropy (1914-1939 rr.): materialy do bibliohr., L'viv 1998, 297 s.

Pryzhmurenko I., Vydannya po taborakh internovanykh ukrayins'kykh voyakiv Armiyi U.N.R., Litopys Chervonoyi Kalyny, L'viv 1931, № 1, 23.

Sribnyak I., Obezzbroyena, ale neskorena: Internovana Armiya UNR u taborakh Pol'shchi y Rumuniyi (1927-1924 rr.), Kyyiv-Filyadel'fiya 1997, 184 s.

Sydorenko N., Natsional'no-dukhovne samostverdzhennya u 3 ch. Presa internovanykh ukrayintsiv ta tsyvil'noyi emihratsiyi (Chekhiya, Pol'shcha, Rumuniya, Yehypet, 1919-1924), Doslidnyts'kyy tsentr istoriyi ukrayins'koyi presy, Kyyiv 2000, T. 2, 262 s.

Tsentral'nyy derzhavnyy arkhiv vyshchykh orhaniv vlady ta upravlinnya Ukrayiny (TsDAVO Ukrayiny), f. 3525 , op. 1, spr. 13, 14; f. 2373, op. 3, spr. 8. 
Pobrane z czasopisma Wschód Europy http://journals.umcs.pl/we

Data: 26/04/2023 11:56:04

Литературные и литературно-юмористические журналы в лагерях интернированных...

Tsentral'nyy derzhavnyy arkhiv zarubizhnoyi ukrayiniky (TsDAZU), f. 15, op. 1, spr. 65.

Vishka O., Presa ukrayins'koyi emihratsiyi v Pol'shchi (1920-1939 rr.: ist.-bibliohr. doslidzh., L'viv 2002, $479 \mathrm{~s}$.

Wiszka E., Prasa emigracji ukraińskiej w Polsce 1920-1939, Wydawnictwo Naukowe Uniwersytetu Mikołaja Kopernika, Toruń 2001, 324 s. 